\title{
CORRECTIONAL STRATEGY AND TACTICS OF EQUILIBRIUM DISORDERS OVERCOMING OF PRESCHOOLERS
}

\author{
Pavel Bochkov \\ Department of Orthopedics and Rehabilitation ${ }^{1}$ \\ pbochkov@ukr.net \\ Nikolay Moga \\ Department of Orthopedics and Rehabilitation ${ }^{1}$ \\ moga2003@ukr.net \\ ${ }^{1}$ National Pedagogic Dragomanov Uneversity \\ 9 Pyrogova str., Kyiv, Ukraine, 01601
}

\begin{abstract}
The article describes planning system features of corrective actions for the balance function formation in preschool children with musculoskeletal system disorders. The analysis of the existing planning approaches of physical education and physical rehabilitation is made: the insufficiency of the substantiated scientific methodological bases in planning of corrective actions for balance function improvement in preschool children with musculoskeletal system disorders is found out. The general principles of adaptive physical education planning of preschoolers with musculoskeletal disorders are considered. On this basis, a method of step-by-step planning of equilibrium function purposeful formation was developed, which reflects the logic of five channels stimulating of the postural aplomb system and takes into account the peculiarities of postural deficit in each case. Conclusions present the algorithm of corrective actions planning system, which improves balance function of the specified children category. Research prospects of effective ways of postural deficit overcoming of preschool children with musculoskeletal system disorders are briefly marked.
\end{abstract}

Keywords: balance function, correction, preschoolers, planning, channels of postural aplomb system, adaptive physical education.

DOI: 10.21303/2504-5679.2020.001397

\section{Introduction}

The development of children's physical qualities requires appropriate planning. Balance is an integral part of the quality of children's dexterity and should also develop purposefully, not spontaneously. Unfortunately, in the academic literature of the theory and methods of preschool children physical education, we could not find scientifically grounded principles of planning [1-4]. There are some recommendations for the preschooler's physical education classes organization, there are general wishes to teachers, but this is not enough to purposefully conduct physical education of this children category throughout the school year and several years of the child in kindergarten.

The traditional approach [5] of the equilibrium development suggests that it is one of the manifestations of coordination abilities. It is believed that two mechanisms should be distinguished for balance maintaining. The first mechanism works when balance maintaining is the main motor task. In this case, the maintenance of a stable posture is the result of a regulatory mechanism that operates on the basis of constant adjustments. Recovery occurs through reflex tension of the synergistic muscles and the corresponding relaxation of the antagonist muscles, and significant disturbances overcoming occurs by rapid reflex movement towards a stable support plane. The second mechanism works when the posture reactions are part of movements with complex coordination, and any of these reactions have a warning (not reflex) nature and are part of the program of motor action. In the implementation of both options, the main role belongs to the processing of afferent information received from analyzers. Primary importance is joint and muscular proprioception, and additional information comes from visual and vestibular analyzers.

It should be noted, when solving the problem of stable maintenance of complex equilibrium, there is a restructuring of freedom degree in the coordinated controlled units, i. e. the actual num- 
ber of parameters that should be adjusted becomes much less than the number of freedom degrees due to joint mobility.

It is believed that any deviation of the body from the optimal position should be accompanied by appropriate adequate efforts to restore it. In such cases, the phenomenon of "hyper compensation" often occurs, when the projection of the common mass center skips the optimal position due to inertia. There are back-oscillating movements, i. e. balancing. But these scientific developments concern the problems of professional sport, Olympic achievements, rather than children's physical rehabilitation, when it comes to maintaining the simplest equilibrium in a stable position of standing and walking.

In some authors [6] we find general recommendations for overcoming the problems associated with imbalance; rehabilitation measures for balance disorders should include:

- therapeutic gymnastics aimed at balance training, stabilization of vision (in the case of vestibular diseases), physical training;

- medical repositioning maneuvers in the presence of BPPD (benign paroxysmal positional dizziness);

- balance exercises using biological feedback methods;

- psychological correction;

- household correction aimed at modifying or creating conditions that facilitate the independent movement of patients suffering from balance disorders [5]. But these recommendations also do not clarify the problems of corrective measures planning.

Interesting ideas are found in the developments of Gage P. and Weber B. and colleagues [7], who recommend "manipulation of the main inputs" of the postural aplomb system: visual, vestibular, oculomotor, proprioceptive and gift. Additionally, experts recommend the use of a number of techniques: aplomb platform, Bess's platform, pencils, texts, chronometer with fractions of a second, thick rope, steps, polyurethane foam mats, etc. But these recommendations are applied more to adults with severe balance problems than to preschoolers with relatively mild variants of this function.

All above determines the relevance of this study.

The aim of the research is to develop a preliminary algorithm for planning corrective measures to improve the function of balance in preschoolers with musculoskeletal system (MS) disorders by means of adaptive physical education.

\section{Research methods}

Theoretical: historical analysis method and information systematization method of domestic and foreign experience of balance function correction in children with MS - was used to study the degree of research and determine the practical application possibility of different physical rehabilitation models of children with musculoskeletal system disorders.

Axiomatic method was used to build the phylogenetic structure of balance function correction in preschoolers and to develop the theoretical basis for its improvement by means of adaptive physical education.

Modeling method was used to create the algorithm of corrective measures planning to improve the balance function in certain children category and to create a working model of the planning system and its further experimental verification.

\section{Results and discussion}

Previously, we have studied the features of planning the physical development of early and preschool age children [8-15]. Let's focus on the basic principles of planning physical education for preschoolers:

1. Phylogenetic principle - reflects the evolutionary logic of the motility formation in animals and humans, from fish and amphibians to homo sapiens. The following statement: «from horizontal (relaxed and slow) starting positions and movements - to vertical (tense and fast)» can briefly illustrate this logic.

This is how the evolution of animals took place. Baby demonstrated such development sequence in the period of early ontogenesis (during the first year of life): mastering locomotor acts 
from primitive movements in the supine position and in crawling to more mature and perfect movements (standing, walking, swimming, running and jumping). Similarly, the preschooler's day begins after a night sleep and after day nap. Therefore, we put this sequence in the basis of physical education planning and rehabilitation of children, because it is the most natural.

2. Age principle - it provides shifting of methodological accents in the planning of physical education classes depending on the age of children. As the skeleton and muscular system of early and preschool age children are still relatively weak, unformed, it makes sense to increase for them the number of exercises in horizontal positions (lying, crawling, sitting), which relieve the musculoskeletal system from gravitational pressure during movements performance. This creates optimal conditions for harmonious physical development and correction of motor disorders in children. Conversely, for older preschool children, the relevance of horizontal positions and movements is significantly reduced - while increasing the importance of vertical, functional, training movements (climbing, running, jumping). It is clear that for middle preschool children, the predominant physical education classes should be the middle (in terms of evolution) motor modes, located between horizontal positions and vertical motor actions (standing and walking).

Thus, the younger child is, the more significant for it starting positions and movements in the horizontal-lying basic motor modes (BMM) (lying, crawling and sitting). Conversely, the older child is, the more relevant for it vertical, functional, training basic motor modes (climbing, running and jumping).

3. Calendar principle. It will help the teacher to choose the content of physical education classes depending on the season (cycle). In this sense, we recommend to follow the traditional planning approach, which has been used for many years in the work of preschool educational institutions - season planning (quarters). From a methodological point of view, we called it cycles:

Autumn cycle: September - October - November (preparatory cycle). It is necessary to lay the foundation for the promising physical development of the child during the school year in autumn. The whole September is devoted for monitoring the children physical development as an important component of the general system of medical and pedagogical control in preschool education. A physical education instructor or educator together with a nurse according to the author's method of Efimenko M. «Game testing of physical development and health of children with normal and limited health» or other methods (other authors) should perform this work. Testing should be performed according to the schedule of physical education classes, i. e. 3 times a week. If necessary, you can use the extra time in the day mode (on a walk, leisure, etc.). The results of monitoring the physical development and motor training of children are recorded in the appropriate protocols, which are presented in the author's manual on game testing. Based on the analysis of such monitoring results, typological groups with one or another type of motor disorders should be formed, and individual correctional programs should be developed to overcome these disorders by means of physical education. The final monitoring of children's physical development is conducted in May, after which it is possible to make conclusions about the effectiveness of healing fitness carried out during the year.

In October and November in all age groups horizontal-lying movement modes (lying crawling - sitting) during physical education classes should dominate. For the rest of BMM is allotted smaller amount of classes.

Winter cycle: December - January - February (supply cycle). In the winter cycle, the training of children in all age groups is focused on greater verticalization of BMM and their dynamization. In this cycle foundation for success in the main (spring) cycle of the school year will be laid. In winter, the middle BMM should become dominant in all age groups - standing-walking, which does not exclude other basic motor modes (but in small volume). You are leading up children to future maximum performance in all major movements in the spring and summer cycles.

Spring cycle: March - April - May (main cycle). The nature bloom involves the maximum children's physical abilities at the end of the school year. Dominant in all age groups in physical education classes are vertical and dynamic main motor modes with heavy loads - climbing, running, jumping. Children must reach their maximum performance in physical development in spring cycle. The final pedagogical diagnosis of children's physical development is expected in May. 
Summer cycle: June - July - August (improvement period). The summer wellness period is most suitable for improving the basic motor skills formed during the school year. The culmination of nature bloom: access to fresh air, landscape physical culture, various natural and artificial obstacles in the environment create excellent conditions for the development of children's variability of basic skills in all basic motor modes. By variability of skills we mean the ability of the child to effectively use the acquired standard skills (during the year) of basic motor modes in non-standard, unusual, relatively complex conditions.

Thus, the essence of the calendar principle can be expressed as: horizontal positions and exercises should be dominated in physical education classes in autumn in all age groups and, conversely, vertical dynamic motor modes should be dominated in spring and summer cycles.

1. Intra-cycle principle - its consideration helps teacher to plan his work in each of the four three-month cycles. The first month of any cycle (for example, December; winter cycle) should consist of horizontal-lying basic motor modes (lying-crawling-sitting). The second month of the cycle (January) is dedicated to the middle BMM (standing-walking). The final, third month of the cycle (February) involves only vertical and functional basic movements (climbing-running-jumps).

2. The repetition principle reflects a well-known proverb in pedagogy: Repetition is the mother of learning! Each school year is built according to the same scheme as the previous one: four calendar cycles (autumn - winter - spring - summer). Both the year and each cycle begin with horizontal positions and end with vertical dynamic basic movements. It may seem that we are standing still and not moving towards the physical development of children, because we repeat the same thing. But this is not so: in each academic year and cycle we repeat only the evolutionary algorithm of mastering the basic motor modes, and not the content of physical education classes. You will learn more about this in the description of the following principle.

3. The principle of steps - it reveals the following rule: in each subsequent cycle (from autumn to summer) the basic motor modes, although repeated, but constantly and gradually become more complicated according to the content of exercises performed in the classroom and the level of physical activity. In other words, crawling in winter should not be like in autumn, and in spring not like in winter. For example, in the fall, the teacher learned with children basic stomping on the spot on the low four. In winter, children under the guidance of a teacher are already crawling on low four back and forth, sideways, diagonally, with a change of direction. In the spring cycle, children must learn to crawl confidently on low fours in a confined space, through mazes, and even carry a correct object on their head (for example, a rubber ring).

The basic principles of planning according to Efimenko M. technology were briefly described above. Now there is a need to adapt them to the specifics of our research ways to improve the balance function in preschoolers with musculoskeletal system disorders. This specificity of planning is reflected in the following patterns [16-29]:

1. The balance function can be stimulated, developed and adjusted, mainly in vertical and orthograde positions sitting, kneeling, standing, walking, when there are conditions of balance loss.

2. Planning of corrective measures to improve balance function in this children category should be associated with the presence of five channels of the postural aplomb system in person (child): vestibular, visual, proprioceptive, plantar and oculomotor, which should be stimulated in the required ontogenetic sequence.

3. Based on the peculiarities of imbalance in preschoolers and the dominant problem with a particular channel of the postural aplomb system - to stimulate the appropriate problem channel, integrating these stimuli with other external and internal channels.

Let us dwell more detail on each of these positions. Synonyms of the term "orthograde" are the words "vertical posture", "orthograde body position", "vertical position of the human body". In the process of human evolution, one of the most expedient and stable dynamic systems was formed - the functional system of antigravity. From the first hours of its fetal development, the child exists in the conditions of the Earth's gravitational field. For constantly counteract the gravitational factor and for undesirable changes compensate in the body, various operative (for urgent adaptation) vestibulo-motor, vestibulo-viscero-vascular and vestibulo-oculomotor reactions are performed. Maintaining a vertical posture, standing and walking - this is one of the 
primary basic functions of human adaptation to existence in the gravitational field of the Earth. Maintaining a vertical pose absorbs the features of the human constitution, integrates his life experience and sometimes demonstrates the functional and pathological features of a particular individual. It is believed that the orthograde position of the body characterizes such motor actions as standing, walking, running and other motor activities. Orthograde pose is associated with such an important biomechanical parameter of human as posture. As we investigate the possibility of improving balance function in preschool children, we have deliberately supplemented the list of these basic orthograde movements with sitting. Thus, the following complexes of verticalized and orthograde exercises can be taken as a basis for the development and balance function correction:

- exercises in a sitting position on the buttocks;

- exercises in a sitting position on the buttocks on the rise;

- exercises in a sitting position on the buttocks on a shaky support;

- exercises in a squatting position;

- exercises in a squatting position on the rise;

- exercises in a semi-squat position;

- exercises in a sitting position (different options) on a non-standard support;

- exercises in the position on low knees on the spot;

- exercises in the position on low knees on a movable support;

- exercises in the position on low knees on a rotating support;

- exercises in the position on low knees on a non-standard support;

- exercises in the position on the middle knees on the spot;

- exercises in the position on the middle knees on a movable support;

- exercises in the position on the middle knees on a rotating support;

- exercises in the position on the middle knees on a non-standard support;

- exercises in the position on high knees on the spot;

- exercises in the position on high knees on a shaky support;

- exercises in the position on high knees on a rotating support;

- exercises in the position on high knees on a non-standard support;

- exercises in a position on one knee with support on the foot of the other leg on spot;

- exercises in a position on one knee with support on the foot of the other leg on a movable support;

- exercises in a position on one knee with support on the foot of the other leg on a rotating support;

- exercises in the position on one knee with support on the foot of the other leg on a non-standard support;

- exercises in movement on high knees on a stable support;

- exercises in movement on high knees on unstable support;

- exercises in moving on high knees on a non-standard support;

- exercises in a standing position on a stable solid support;

- exercises in a standing position on an unstable solid support;

- exercises in a standing position on an elastic support;

- exercises in a standing position on a rotating support;

- exercises in the standing position on a non-standard support;

- exercises in a standing position on one leg on a stable solid support;

- exercises in a standing position on one leg on an unstable solid support;

- exercises in a standing position on one leg on an elastic support;

- exercises in a standing position on one leg on a rotating support;

- exercises in a standing position on one leg on a non-standard support;

- walking exercises on a solid stable support;

- walking exercises on a solid unstable support;

- walking exercises on an elastic unstable support;

- walking exercises on limited support; 
- walking exercises on high support;

- walking exercises on limited and increased support.

Let us consider the second aspect of the development of an algorithm for planning corrective measures to improve the balance function in preschoolers - "manipulation of the entrances" of the postural aplomb system. We see this direction as the most promising in terms of developing appropriate methodological content for the correction of the problem function. Previously, we have studied the main means of balance function correcting in preschoolers with MS disorders using the possibilities of adaptive physical education [30]. We concluded that the basic sequence of equilibrium function training should reflect the phylogenetic and ontogenetic logic of the formation and functioning of the main channels of the postural aplomb system and be as follows:
A. Vestibular training.
B. Vestibular-visual training.
C. Vestibular-visual-proprioceptive training.
D. Vestibular-visual-proprioceptive-plantar training.
E. Oculomotor training (vestibular-visual-proprioceptive-plantar training-oculomotor training).

It can be represented as:

$$
\mathrm{A} \rightarrow \mathrm{AB} \rightarrow \mathrm{ABC} \rightarrow \mathrm{ABCD} \rightarrow \mathrm{E}(\mathrm{ABCDE}) .
$$

But this approach reflects the ideal sequence of gradual formation of the balance function in a healthy child. It is logical to assume that it can tactically change according to the peculiarities of imbalance in children, especially - from the dominant disturbance of a particular channel of the postural aplomb system. For example, stabilography revealed that the dominant disturbance of the balance system is in the vestibular apparatus. In this case, the corrective action planning algorithm described above won't be changed. It will be increased only amount of exercises to stimulate vestibular function. If the dominant disturbance channel is visual system, it will be necessary to begin training with exercises that stimulate the development of the child's vision and only then add stimulation of the vestibular balance system. If the dominant disturbance channel is proprioceptive muscular system, it will be necessary to start training with it and over time, this stage of correction should be the longest.

The most affected may be two or even three channels of the postural aplomb system. In this case, it is also necessary to begin with corrective measures by means of adaptive physical education, following to the appropriate "ideal" sequence of their stimulation. For example, the vestibular and proprioceptive systems are affected. In this case it is necessary to begin with stimulation of vestibular system at first, and this stage will be the longest. Next, focus on the proprioceptive system of the musculoskeletal system. These two stages will be the most capacious in terms of time and content. After raising the levels of functioning of these channels to the required ones, it is necessary to move to integrated coordination influences, gradually supplementing the informational postural flows with additional information from other channels.

Study limitations. The corrective actions performing requires consideration of contraindications, which include the following:

The child does not need to be forced to perform exercises if he absolutely does not want this at the moment.

Vestibular training should be limited or completely excluded if the child has a headache, has nausea, has a pale complexion and inappropriate behavior (motor-game reactions, emotions).

If the child is afraid of doing exercises with closed eyes, it is necessary to use a translucent bandage or darkened glasses (sunglasses). In order to soften the mode of performing such exercises.

In our review study, we relied on the preliminary hypothesis that the activity of one or more channels of the aplomb postural system may be inhibited for one or another reason in children with equilibrium function disturbance: congenital malformations, consequences of birth trauma of central nervous system, postpartum skull, spine or lower extremities injuries. For this reason, the overall balance function of the child suffers. But we have not fully investigated the hypothesis that 
the functioning of the postural channels can be preserved, but at the same time the coordination of their mutual activity is disrupted, which leads to a deterioration or imbalance in children.

Prospects for further research. The prospect of future research may consist of studying of coordination violations during cooperative activity: between two channels of the aplomb postural system (vestibular and visual); between three (vestibular-visual-proprioceptive); between four (vestibular-visual-proprioceptive-gift) and, finally, between all five channels (vestibular-visual-proprioceptive-gift-oculomotor). At the same time, it is interesting to study the dominant violation of coordination relationships and exercises developing to overcome this leading coordination violation.

In future studies, it is necessary to pay attention to coordination disorders in the activity not only of the channels (vestibular and visual) that are adjacent to the ontogenetic logic of development, but also coordination connections (for example, vestibular and proprioceptive or visual and gift, etc.) that more remote in ontogenesis.

\section{Conclusions}

Summing up the results of theoretical study, we formulate introductory conclusions:

1. It is important to start training the channel that has affected the most. Visually, it can be represented as follows:

$$
\begin{aligned}
& \mathrm{A} \rightarrow \mathrm{B} \rightarrow \mathrm{c} \rightarrow \mathrm{D} \rightarrow \mathrm{E}, \\
& \mathrm{c} \rightarrow \mathrm{A} \rightarrow \mathrm{B} \rightarrow \mathrm{D} \rightarrow \mathrm{E},
\end{aligned}
$$

where $\mathrm{c}$ is the most affected channel.

2. In terms of time, the training of this channel should be the longest:

$$
\mathrm{c} \rightarrow \rightarrow \mathrm{A} \rightarrow \mathrm{B} \rightarrow \mathrm{D} \rightarrow \mathrm{E} .
$$

3. Further to this channel, it is necessary to add trainings of other channels in integrated way, taking as a basis the ideal algorithm of balance development in the healthy child formulated above:

$$
\mathrm{c} \rightarrow \rightarrow \mathrm{A} \rightarrow \mathrm{AB} \rightarrow \mathrm{ABC} \rightarrow \mathrm{ABCD} \rightarrow \mathrm{E}(\mathrm{ABCDE})
$$

4. If two or more channels were most affected, they should also be stimulated first by the degree of damage, and then, following the "ideal" sequence, move to integrated coordination effects, gradually supplementing information postural flows with additional information from other channels:

$$
\begin{gathered}
\mathrm{a}-\mathrm{B}-\mathrm{c}-\mathrm{D}-\mathrm{E}, \\
\mathrm{a} \rightarrow \rightarrow \mathrm{c} \rightarrow \rightarrow \mathrm{B} \rightarrow \mathrm{D} \rightarrow \mathrm{E}, \\
\mathrm{a} \rightarrow \rightarrow \mathrm{aB} \rightarrow \mathrm{aBc} \rightarrow \mathrm{aBcD} \rightarrow \mathrm{aBcDE}, \\
\mathrm{A} \rightarrow \mathrm{AB} \rightarrow \mathrm{ABC} \rightarrow \mathrm{ABCD} \rightarrow \mathrm{ABCDE} .
\end{gathered}
$$

\section{References}

[1] Vilchkovskyi, E. S. (1998). Teoriia i metodyka fizychnoho vykhovannia ditei doshkilnoho viku. Lviv: VNTL, 335.

[2] Vilchkovskyi, E. S., Denysenko, N. F. (2008). Orhanizatsiia rukhovoho rezhymu u doshkilnykh navchalnykh zakladakh. Ternopil: Mandrivets, 128.

[3] Alpatskaia, E. V. (2004). Vozrastnoe vliianie koordinatsionnykh sposobnostei na formirovanie osnovnykh dvigatelnykh umenii i navykov detei 4-6 let. Smolensk, 132. 
[4] Besshaposhnikova, S. Iu. (2006). Razvitie dvigatelnoi koordinatsii u detei 5-7 let s ispolzovaniem gimnasticheskikh uprazhnenii na umenshennoi opore. Shuia, 181.

[5] Krutsevich, T. Iu. (Ed.) (2003). Teoriia i metodika fizicheskogo vospitaniia. Vol. 1. Kyiv: Olimpiiskaia literatura, 423.

[6] Belova, A. N. (2000). Neiroreabilitatsiia. Moscow: Antidor, 567.

[7] Gazhe, P.-M., Veber, B. et. al. (2008). Posturologiia. Reguliatsiia i narusheniia ravnovesiia tela cheloveka. Saint Petersburg: Izdatelski dom SPbMAPO, 316.

[8] Yefymenko, M. M. (2014). Dyferentsiiovanyi pidkhid do fizychnoi reabilitatsii doshkilnykiv iz porushenniamy oporno-rukhovoho aparatu. Osoblyva dytyna: navchannia i vykhovannia, 3, 61-68.

[9] Efymenko, N. N. (2012). Napravlennost korrektsyonnoho fyzycheskoho vospytanyia detei s narushenyiamy oporno-dvyhatelnoho aparata. Naukovi zapysky. Seriia: Pedahohichni nauky, 107, 177-185.

[10] Efimenko, N. N. (2011). Novye podkhody k fizicheskomu vospitaniiu i ozdorovleniiu detei doshkolnogo i mladshego shkolnogo vozrasta. Doshkolnoe obrazovanie, 1, 48-58.

[11] Yefymenko, M. M. (2012). Perspektyvy korektsiinoho fizychnoho vykhovannia ditei z porushenniamy oporno-rukhovoho aparatu v inkliuzyvnii doshkilnii osviti. Humanizatsiia navchalno-vykhovnoho protsesu, 9, 281-286.

[12] Yefymenko, M. M. (2013). Suchasni pidkhody do korektsiino spriamovanoho fizychnoho vykhovannia doshkilnykiv z porushenniamy oporno-rukhovoho aparatu. Vinnytsia: Nilan-LTD, 356.

[13] Bochkov, P. N. (2019). Model formyrovanyia posturalnikh mekhanyzmov u detei s narushenyiamy oporno-dvyhatelnoho apparata sredstvamy korrektsyonnoho fyzycheskoho vospytanyia. Naukovi zapysky kafedry pedahohiky Kharkivskoho natsionalnoho universyteta im. V. N. Karmazina, 44, 24-33.

[14] Yefymenko, M. M., Bochkov, P. M. (2015). Planuvannia zaniat z fizychnoi kultury dlia ditei rannoho ta doshkilnoho viku. Vypusk 1. Osinnii tsykl: veresen - zhovten - lystopad. Vinnytsia: TOV «Nilan-LTD», 108.

[15] Yefymenko, M. M., Bochkov, P. M. (2015). Planuvannia zaniat z fizychnoi kultury dlia ditei rannoho ta doshkilnoho viku. Vypusk 2. Zymovyi tsykl: hruden - sichen - liutyi. Vesnianyi tsykl: berezen - kviten - traven. Litnii tsykl: cherven - lypen serpen. Vinnytsia: TOV «Nilan-LTD», 250.

[16] Usachev, V. I. (1995). Vzaimodeistvie vestibuliarnoi, opticheskoi i propriotseptivnoi sensornykh sistem v protsesse realizatsii vraschatelnogo nistagma. Sensornye sistemy, 9 (4), 42-48.

[17] Usachev, V. I. (1996). Kontseptsiia statokineticheskoi sistemy organizma. Teoreticheskie i prakticheskie problemy sovremennoi vestibulologii. Saint Petersburg, 117-119.

[18] Usachev, V. I., Sliva, S. S., Beliaev, V. E., Pereiaslov, G. A., Pechorin, P. E. (2006). Novaia metodologiia obrabotki stabilometricheskoi informatsii i problemy shirokogo vnedreniia ee v praktiku. Izvestiia IUFU. Tekhnicheskie nauki, 11 (66), $138-144$.

[19] Usachev, V. I., Dotsenko, V. I., Kononov, A. F., Artemov, V. G. (2009). Novaia metodologiia stabilograficheskoi diagnostiki narusheniia funktsii ravnovesiia tela. Vestnik otorinolaringologii, 3, 19-21.

[20] Usachev, V. I. (1995). Prostranstvennoe chuvstvo, vestibuliarnii apparat i statokineticheskaia sistema. Materialy KHV Vseros. sezda otorinolaringologov. Saint Petersburg, 1, 49-54.

[21] Usachev, V. I. (2001). Pat. No. 2175851 RU. Sposob kachestvennoi otsenki funktsii ravnovesiia. MPK: A61B5/103.

[22] Usachev, V. I. (2011). Stabilometricheskie parametry: pamiatka nachinaiuschemu polzovateliu. Taganrog: Ritm, 29.

[23] Mokhov, D. E., Usachev, V. I. (2004). Stabilometriia v posturologii. Saint Petersburg: MAPO, 20.

[24] Usachev, V. I.; Soldatov, I. B., Gofman, V. R. (Eds.) (2000). Fiziologiia i klinicheskie metody issledovaniia vestibuliarnogo apparata. Otorinolaringologiia. Saint Petersburg, 75-96.

[25] Babiiak, V. I., Ianov, Iu. K. (2007). Vestibuliarnaia funktsionalnaia sistema. Saint Petersburg: Gippokrat, 432.

[26] Beseda, V. V. (2015). Differentsirovannii podkhod k korrektsii narushenii oporno-dvigatelnogo apparata u detei 3-6 let. Odessa, 217.

[27] Gerasimchik, M. V. (2001). Osobennosti podderzhaniia ravnovesiia pri razlichnykh narusheniiakh pozy tsentralnogo geneza. Vestnik prakticheskoi nevrologii, 3, 21-23.

[28] Gribanov, A. V., Sherstennikova A. K. (2013). Fiziologicheskie mekhanizmy reguliatsii posturalnogo balansa cheloveka: (obzor). Vestnik Severnogo (Arkticheskogo) federalnogo universiteta. Seriia: Mediko-biologicheskie nauki, 4, $20-29$.

[29] Bochkov, P. N. (2019). Osnovnye sredstva formirovaniia i korrektsii posturalnykh mekhanizmov u doshkolnikov s narusheniiami oporno-dvigatelnogo apparata. Naukovi zapiski Berdianskogo derzhavnogo pedagogichnogo universitetu. Seriia: Pedagogichni nauki, 1, 134-145.

[30] Zamergrad, M. V. (Ed.) (2018). Diagnostika i lechenie narushenii ravnovesiia pri zabolevaniiakh nervnoi sistemy. Moscow: MEDpress-inform, 112 . 